\title{
Responses in Growth and Lipid Productivity of Chlorella Vulgaris to Different Nitrogen Sources
}

\author{
D. Ananda Kumar ${ }^{1}$, T. Gopal ${ }^{1}$, K. Harinath ${ }^{1}$ and Sibi $G^{{ }^{1}}$
}

${ }^{1}$ Department of Biotechnology, Indian Academy Degree College-Autonomous, Centre for Research and Post Graduate Studies, Bengaluru, India

Received: 21 February, 2017; Accepted: 22 March, 2017; Published: 20 April, 2017

*Corresponding author: Sibi G, Department of Biotechnology, Indian Academy Degree College-Autonomous, Centre for Research and Post Graduate Studies, Bengaluru, India. E-mail: gsibii@gmail.com

\begin{abstract}
Background: Nutrient compositions of the growth medium, nitrogen in particular, influence the microalgal biomass and lipid productivity.

Materials and Methods: Chlorella vulgaris was cultivated under varying nitrogen sources in the form of ammonium acetate $\left(\mathrm{NH}_{4}-\mathrm{N}\right)$, calcium nitrate $\left(\mathrm{NO}_{3}-\mathrm{N}\right)$, glycine, sodium nitrite $\left(\mathrm{NO}_{2}-\mathrm{N}\right)$ and urea to improve biomass and lipid productivity. Specific growth rate, dry cell weight, cellular pigments, biomass concentration were taken as measurement of cell growth and lipid productivity was determined at the end of cultivation period.
\end{abstract}

Results: $\mathrm{NO}_{3}-\mathrm{N}$ was demonstrated to be the best nitrogen source for both biomass and lipid-producing potential of $C$. vulgaris with $0.34 \mathrm{~g} \mathrm{~L}^{-1}$ day and $0.126 \mathrm{~g} \mathrm{~L}^{-1}$ day, respectively. The other nitrogen sources contributed to algal lipid-producing potential were $\mathrm{NO}_{2}-\mathrm{N}$ and $\mathrm{NH}_{4}-\mathrm{N}$

Conclusion: The findings suggests that the identification of appropriate $\mathrm{N}$ source provides an economically feasible strategy to obtain biomass and lipid productivity from microalgae simultaneously.

Keywords: Microalgae; Chlorella Vulgaris; Nitrogen; Nitrate; Biomass; Lipid

\section{Introduction}

Physiological composition of growth medium produces biochemical changes in microalgae which is also species-specific. In other words, change in the nutrient environment not only affect photosynthesis and growth rate of microalgae but also result in increase or decrease of cellular macromolecular composition [13]. Nitrogen is necessary for the synthesis of proteins, nucleic acids and chlorophyll in microalgae [4]. Microalgae assimilated the inorganic nitrogen into biochemically active compounds for their physiological needs. Nitrogen is found to enhance the biomass and lipid production in microalgae and the form of nitrogen available to the microalgae affects its cellular composition and lipid content. Identification of appropriate nitrogen source and its concentration have influence on microalgal growth as well as lipid accumulation [5-8].

Biodiesel derived from microalgae is one of the promising alternatives of renewable energy due to year round production, higher productivity than terrestrial energy crops. Due to the high growth rate and high oil contents, Chlorella spp. showed great potentials for biodiesel production. Heterotrophic and mixotrophic cultures of microalgae have an edge over photo autotrophy as the cell density of phototrophic culture is low which make it hard to be applied in large scale biomass production [9]. Effects of various nutrient sources on biomass and lipid production of Chlorella have been reported previously and have been reported to adapt to heterotrophic cultivation [10]. Nitrogen deficiency induced lipid production in microalgae is well documented; however, nitrogen reduction results in decreased carbon dioxide fixation, oxygen evolution, chlorophyll content and biomass production. These results suggest that effect of nitrogen source and concentration is important to attain a better understanding of the behaviour of algal cells for higher biomass and lipid production. Unfolding which nitrogen source influence algal growth and metabolic functions is critical for successful scale up of microalgal culture for biofuel production. This study focused on the identification of most appropriate nitrogen source for the cultivation of Chlorella vulgaris in order to improve biomass and lipid productivity.

\section{Materials and Methods}

\section{Algal strain and Nitrogen sources}

Chlorella vulgaris isolated from sewerage treatment plant, in Bengaluru $\left(13^{\circ} 04^{\prime} \mathrm{N}, 77^{\circ} 58^{\prime} \mathrm{E}\right)$ was used to study the effects of nitrogen sources on its growth and lipid productivity. Five different nitrogen sources including ammonium acetate 
$\left(\mathrm{NH}_{4}-\mathrm{N}\right)$, calcium nitrate $\left(\mathrm{NO}_{3}-\mathrm{N}\right)$, glycine, sodium nitrite $\left(\mathrm{NO}_{2}-\mathrm{N}\right)$ and urea were used in this study.

\section{Experimental conditions}

The experimental set up were carried out in Erlenmeyer flasks under controlled laboratory conditions (temperature $25^{\circ} \mathrm{C}$, light intensity of $60 \mu \mathrm{mol}$ photons $\mathrm{m}^{-2} \mathrm{~s}^{-1}$ and a light/dark cycle of $12 \mathrm{~h} / 12 \mathrm{~h}$ ) using Bold's Basal medium. Sodium nitrate was used as the nitrogen source for control and the experimental cultures received nitrogen content equivalent to control cultures. All experiments were carried out in triplicates for a period of 14 days.

\section{Specific growth rate and Biomass productivity}

Specific growth rate $(\mu)$ of the microalgae was calculated according to the following formula [11].

$$
\mu=\frac{\ln \left(N_{t} / N_{0}\right)}{T_{t}-T_{0}}
$$

Where, $\mathrm{N}_{\mathrm{t}}$ and $\mathrm{N}_{0}$ are the total cells at the end of log phase $\left(\mathrm{T}_{\mathrm{t}}\right)$ and start of log phase $\left(\mathrm{T}_{0}\right)$, respectively.

Biomass $\left(\mathrm{g} \mathrm{L}^{-1}\right)$ of $C$. vulgaris grown under different nitrogen sources was determined by measuring the optical density of samples at $600 \mathrm{~nm}\left(\mathrm{OD}_{600}\right)$ using UV-Vis spectrophotometer. Biomass concentration was then calculated by multiplying $\mathrm{OD}_{600}$ values with 0.6 , a predetermined conversion factor obtained by plotting $\mathrm{OD}_{600}$ versus dry cell weight (DCW). DCW was determined gravimetrically by centrifuging the algal cells $(3,000 \times \mathrm{g}, 10 \mathrm{~min})$ and drying.

Biomass concentration $=\mathrm{OD}_{600} \times 0.6$

The biomass productivity $\left(\mathrm{g} \mathrm{L}^{-1} \mathrm{~d}^{-1}\right)$ was calculated according to Eq. (2)

Biomass productivity $=\left(\mathrm{B}_{\mathrm{t}}-\mathrm{B}_{0}\right) /\left(\mathrm{T}_{\mathrm{t}}-\mathrm{T}_{0}\right)$

Yield was calculated from the Eq. (3)

Yield $(\mathrm{g} / \mathrm{L})=\left(\mathrm{B}_{\mathrm{t}}-\mathrm{B}_{0}\right) \times$ Volume of culture

Where $B_{t}$ was the biomass concentration at the end of cultivation period $\left(\mathrm{T}_{\mathrm{t}}\right)$ and $\mathrm{B}_{0}$ is the initial biomass concentration at the beginning of the cultivation period $\left(\mathrm{T}_{0}\right)$.

\section{Chlorophyll estimation}

Chlorophyll contents of the microalga were estimated according to Becker [12]. Algal cells were centrifuged and extracted with acetone overnight. The extract was centrifuged at $3000 \times \mathrm{g}$ for $5 \mathrm{~min}$ and the chlorophyll content in the supernatant were determined by measuring the optical densities at 645 and $663 \mathrm{~nm}$ in a spectrophotometer and then calculated using the Eq. (4).

$$
\operatorname{Chl}(\mathrm{mg} / \mathrm{L})=8.02 \times \mathrm{OD}_{663}+20.21 \times \mathrm{OD}_{645} \ldots \ldots \ldots \ldots . . . . . \text { Eq. (4) }
$$

\section{Carotenoids Estimation}

Carotenoids were determined by following the procedure of Whyte [13]. Algal cells were centrifuged and treated with $\mathrm{KOH}(60 \% \mathrm{w} / \mathrm{w})$. The mixture was homogenized and warmed to $40^{\circ} \mathrm{C}$ for $40 \mathrm{~min}$ and extracted using ethyl ether. The solvent was evaporated followed by resuspending in acetone and the optical density was measured at $444 \mathrm{~nm}$. Total carotenoids were calculated using the Eq.(5).

$$
\mathrm{Ct}(\mathrm{mg} / \mathrm{L})=4.32 \times \mathrm{OD}_{444}-0.0439 .
$$

\section{Lipid productivity}

Total lipid of the microalgae was extracted in a Soxhlet extractor using ethyl ether $(1: 100 \mathrm{w} / \mathrm{v})$ and refluxed at $65^{\circ} \mathrm{C}$ for $12 \mathrm{~h}$. The extract was distilled at $50^{\circ} \mathrm{C}$ and the residue was dried at $80^{\circ} \mathrm{C}$ for $2 \mathrm{~h}$. Lipid content was calculated by dividing the residue weight with the dry cell weight. The lipid productivity was calculated by the Eq. (6).

$$
\text { Lipid Productivity }(g / L / \text { day })=\frac{C_{\text {Lipid }}(g / g) \times D C W(g / L)}{\text { Time }}
$$

Where $\mathrm{C}_{\text {Lipid }}$ is lipid content of cells, DCW is dry cell weight, and Time is the cultivation period in days

\section{Results and Discussion}

Nitrogen source is important in biomass productivity of microalgae and to investigate an optimal nitrogen source for cell growth and lipid accumulation, various nitrogen sources were examined. In general, microalgae utilize ammonium, nitrate, urea and nitrite as the primary nitrogen sources [14,15]. The microalgae $C$. vulgaris was able to respond to nitrogen nutrient changes by inducing specific amino acid transport systems [16].

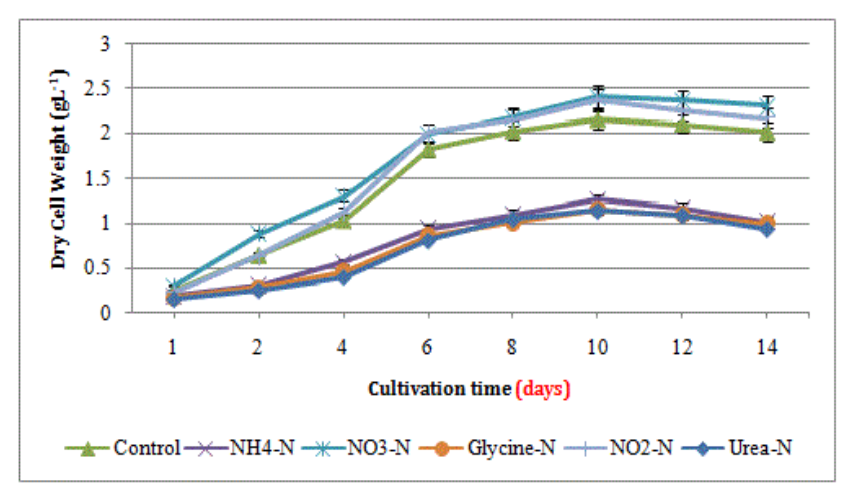

Figure 1: Cell growth of $C$. vulgaris cultivated in varying nitrogen sources

As shown in Figure 1, urea- $\mathrm{N}, \mathrm{NH}_{4}-\mathrm{N}$ and glycine- $\mathrm{N}$ can only support rather poor growth of Chlorella under the investigated conditions. $\mathrm{NO}_{3}-\mathrm{N}$ in the form of calcium nitrate was the best among the nitrogen sources tested $(\mathrm{p}<0.001)$. $\mathrm{NO}_{3}-\mathrm{N}$ led to the highest biomass concentration of $2.41 \mathrm{~g} \mathrm{~L}-1$ which was more than doubling that obtained with urea and glycine $\left(1.14\right.$ and $1.15 \mathrm{~g} \mathrm{~L}^{-1}$, 
respectively). The second other highest biomass concentration was obtained with $\mathrm{NO}_{2}-\mathrm{N}$ (sodium nitrite) which is $9.5 \%$ lesser than $\mathrm{NO}_{3}-\mathrm{N}$; however, there was no much difference in specific growth rates $(\mu)\left(0.082\right.$ and 0.081 day $\left.^{-1}\right)$ under both the nitrogen sources (data not shown). Biomass productivity was calculated using biomass concentration and a highest productivity of $0.34 \mathrm{~g}$ $\mathrm{L}^{-1}$ day $^{-1}$ was obtained in medium supplemented with $\mathrm{NO}_{3}-\mathrm{N}$. Both $\mathrm{NO}_{2}-\mathrm{N}$ and $\mathrm{NO}_{3}-\mathrm{N}$ have recorded similar values of $0.29 \mathrm{~g} \mathrm{~L}^{-1}$ day ${ }^{-1}$ (Figure 2).

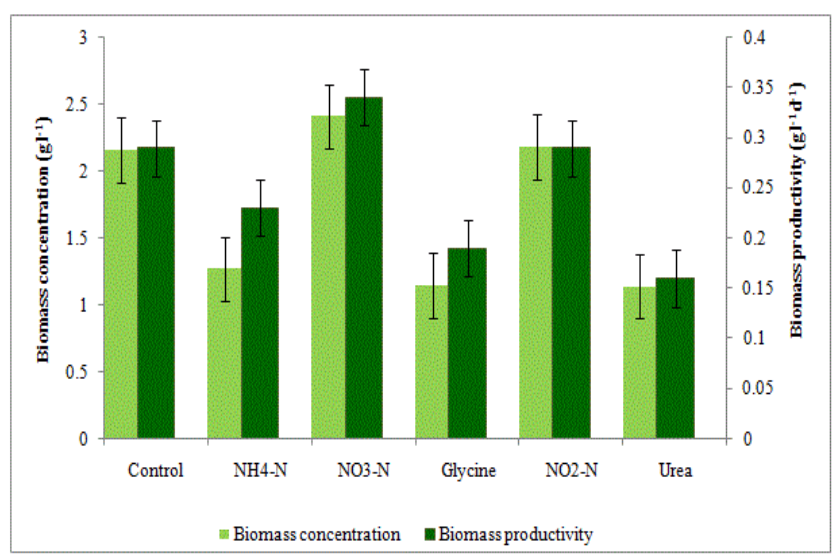

Figure 2: Biomass content and productivity of $C$. vulgaris cultivated in varying nitrogen sources

Urea is preferred as $\mathrm{N}$ source for large scale cultivation of microalgae as it is less expensive; however, in this study urea is proved as least effective $\mathrm{N}$ source, producing a biomass of $0.16 \mathrm{~g}$ $\mathrm{L}^{-1}$ day $^{-1}$. Ammonium as $\mathrm{N}$ source has barely supported the growth of $C$. vulgaris which might be due to assimilation of ammonium ions that resulted in lower pH. Although microalgae can grow over wide $\mathrm{pH}$, the growth is species dependent. The findings were in correlation with previous studies where ammonium resulted in lesser growth $[17,18]$.

The critical day of biomass growth was identified once the growth rate started to decrease rapidly. Biomass yield was calculated using biomass concentration at the beginning and end of cultivation period (Figure 3). Maximum biomass yield of $16.3 \mathrm{~g}$ $\mathrm{L}^{-1}$ was obtained with $\mathrm{NO}_{3}-\mathrm{N}$ followed by $\mathrm{NO}_{2}-\mathrm{N}\left(13.6 \mathrm{~g} \mathrm{~L}^{-1}\right)$. Urea and glycine has recorded the least biomass yield at the end of 14 days cultivation period.

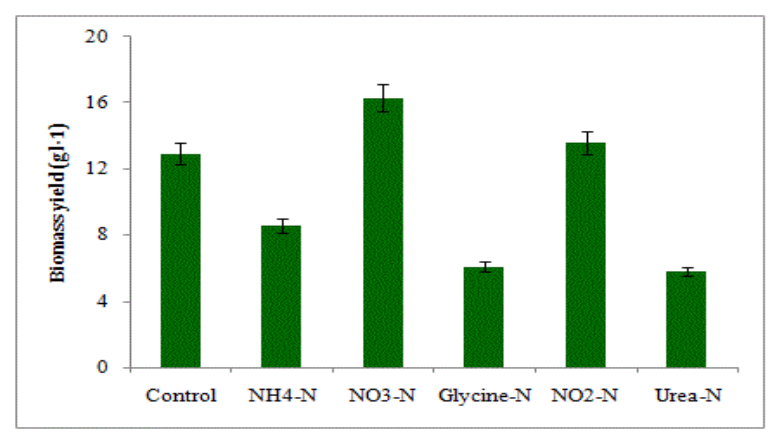

Figure 3: Biomass yield $\left(\mathrm{g} \mathrm{L}^{-1}\right)$ of $C$. vulgaris cultivated in varying nitrogen sources
Chlorophyll is considered as an algal biomass measurement and higher chlorophyll content under $\mathrm{NO}_{3}-\mathrm{N}$ revealed it as the better source for increasing photosynthetic efficiency which would also promote the biomass production. Carotenoids content of the cells grown under various nitrogen sources were determined spectophotometrically in which $\mathrm{NO}_{3}-\mathrm{N}$ and $\mathrm{NO}_{2}-\mathrm{N}$ has produced more pigment levels. It was noted that $\mathrm{NO}_{3}-\mathrm{N}$ in the form of sodium nitrate has produced more carotenoid in algal cells which is new under the investigated conditions. In general, growth parameters in terms of specific growth rate, biomass level and chlorophyll contents were higher in cells grown under calcium nitrate and sodium nitrite throughout the experiment.

The chlorophyll contents of cells grown under different nitrogen sources are shown in Figure 4. From the results, highest chlorophyll content was observed in $\mathrm{NO}_{3}-\mathrm{N}$ followed by $\mathrm{NO}_{2}-\mathrm{N}$. In other studies, urea was found to increase the chlorophyll content of microalgae whereas the present study obtained lowest chlorophyll content in urea and glycine [19-20].

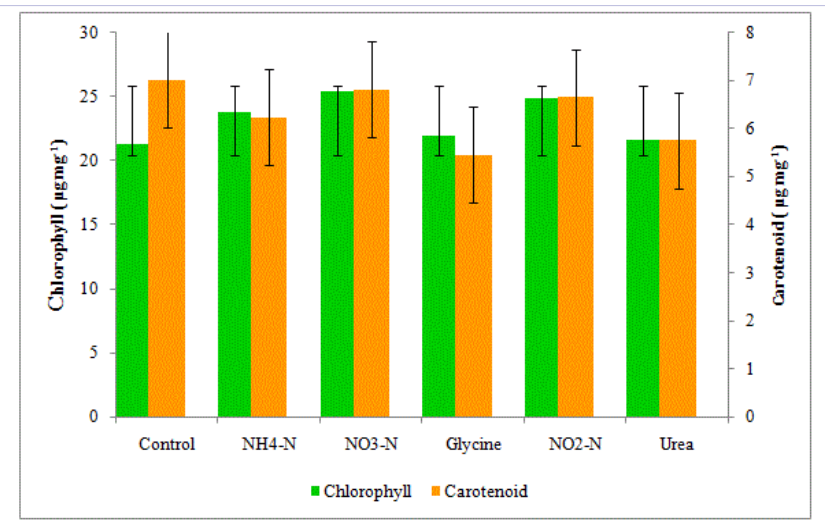

Figure 4: Chlorophyll and carotenoid contents of $C$. vulgaris cultivated in varying nitrogen sources

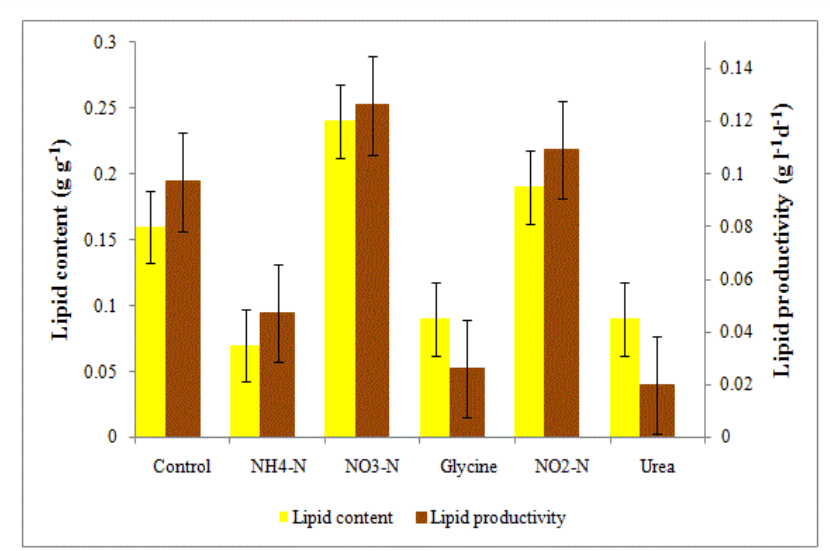

Figure 5: Lipid content and lipid productivity of $C$. vulgaris cultivated in varying nitrogen sources

Figure 5 shows the lipid cell contents (g/g) in dry cells and lipid productivity obtained at different nitrogen sources. In the present study, the highest lipid content $(0.24 \mathrm{~g} / \mathrm{g})$ was found in $\mathrm{NO}_{3}$-N treatment which was 1.26 fold higher than $\mathrm{NO}_{2}-\mathrm{N}$ treatment 
( $p<0.001), 3.4$ fold higher than $\mathrm{NH}_{4}-\mathrm{N}$ treatment $(p<0.001), 2.6$ fold higher than urea- $\mathrm{N}(p<0.01)$ respectively (one-way ANOVA, LSD multiple comparisons test). The lipid productivity of cultures provided with $\mathrm{NH}_{4}-\mathrm{N}$, glycine- $\mathrm{N}$ and urea- $\mathrm{N}$ remained around 0.020-0.047 ( $\mathrm{g} \mathrm{L}^{-1}$ day $\left.^{-1}\right)$. A significant increase to $0.126 \mathrm{~g} \mathrm{~L}^{-1} \mathrm{day}^{-1}$ in $\mathrm{NO}_{3}-\mathrm{N}$ and $0.109 \mathrm{~g} \mathrm{~L}^{-1}$ day ${ }^{-1}$ in $\mathrm{NO}_{2}-\mathrm{N}$ supplemented cultures were recorded $(p<0.01)$. The lipid productivity obtained with $\mathrm{NO}_{3}-\mathrm{N}$ was highest under the investigated condition which was approximately 6.3 times of that of urea- $\mathrm{N}$ and 4.8 times of that obtained with glycine-N.
This study finds best nitrogen source for both biomass content and lipid productivity by $C$. vulgaris. In general, there is a contradiction with biomass and lipid productivity and is depending on the initial nutrient concentrations [8,21]. It is well documented that microalgae accumulate more lipid under nitrogen deprived conditions [22-25]. However, the response towards nutrient conditions is highly dependent on the species and strain investigated. Studies on the effect of nitrogen sources on the growth and lipid content in algae are reported and the algal lipid production is greatly affected by nitrogen sources and concentrations (Table 1).

\begin{tabular}{|c|c|c|c|c|}
\hline Species & $\begin{array}{l}\text { Biomass } \\
\left(g^{-1} d^{-1}\right)\end{array}$ & $\begin{array}{c}\text { Lipid } \\
\left(\mathrm{mg} \mathrm{L}^{-1} \mathrm{day}^{-1}\right)\end{array}$ & $\begin{array}{c}\text { Lipid } \\
\%\end{array}$ & References \\
\hline C. vulgaris & $(0.52) / 14$ & 14.9 & - & Illman et al. [37] \\
\hline C. protothecoides & 19.6 & NA & - & Shi et al. [26] \\
\hline C. vulgaris & - & 20.44 & - & Converti et al. [39] \\
\hline C. protothecoides & $11.7 / 9$ & 654 & 50.5 & Shen et al. [40] \\
\hline C. saccharophila & $1.1 / 7$ & - & 37 & Isleten-Hosoglu et al. [10] \\
\hline C. zofingiensis & $(0.196) / 28$ & 68.1 & 33.5 & Feng et al. [41] \\
\hline Chlorella sp. & $(1.2) / 36$ & 600 & - & Amin et al. [42] \\
\hline C. sorokiniana & $0.218 / 16$ & - & 61.52 & Ramanna et al. [18] \\
\hline C. ellipsoidea & NA & 9.27 & - & Gonzalez-Garcinuno et al. [28] \\
\hline Chlorella sp. & 1.673 & 665 & - & Leesing et al. [30] \\
\hline C. protothecoides & $0.605 / 7$ & 287 & 48.7 & Fei et al. [43] \\
\hline Chlorella sp. & $(0.357) / 45$ & 126.25 & - & Zhan et al. [29] \\
\hline C. sorokiniana & NA & 883 & - & Choi et al. [44] \\
\hline C. vulgaris & $(0.34) / 14$ & 126 & - & Present study \\
\hline
\end{tabular}

To obtain biofuel from microalgae in an economically viable way, it is necessary to enhance the microalgal biomass and lipid productivity. Nutrients play key role in affecting both biomass and production and lipid accumulation in microalgae. Various nitrogen sources such as ammonia, nitrate, nitrite, and urea, can be used to cultivate microalgae. Urea $[18,26]$, ammonium [27,28], nitrite [29] and nitrate [30] were found to produce highest biomass and lipid production in various Chlorella species. Whereas, nitrate was found as the best nitrogen source for both growth and lipid production in other microalgae [3136]. In general, decreased $\mathrm{N}$ source concentration reduces the biomass productivity and increases lipid content which is due to reduced metabolism rate resulted in channeling of excess carbon towards storage molecules production such as triacylglycerides. Although studies have suggested that nitrogen starvation is most promising culture strategy to increase the lipid productivity, efforts should be taken to improve both biomass and lipid productivity simultaneously.

\section{Conclusion}

In this study, $\mathrm{NO}_{3}-\mathrm{N}$ was demonstrated to be the best nitrogen source for both biomass and lipid-producing potential of Chlorella vulgaris under the investigated conditions. Meanwhile, $\mathrm{NO}_{2}-\mathrm{N}$ and $\mathrm{NH}_{4}-\mathrm{N}$ also contributed to algal lipid-producing potential, but not urea-N and glycine-N. Identification of appropriate $\mathrm{N}$ source provides an economically feasible strategy to obtain biomass and lipid productivity from microalgae at the same time. However, nutrient concentration plays a vital role in using microalgae as feedstock suggest that further research should be focused on optimizing the concentration of suitable nitrogen source for improving biomass and lipid productivity of C. vulgaris.

\section{References}

1. Giordano M, Kansiz M, Heraud P, Beardall J, Wood B, et al. Fourier transform infrared spectroscopy as a novel tool to investigate changes in intracellular macromolecular pools in the marine microalga Chaetoceros muellerii (Bacillariophyceae), J. Phycol. 2001;37:271-279. 
2. Hsieh $\mathrm{CH}, \mathrm{Wu}$ WT. Cultivation of microalgae for oil production with a cultivation strategy of urea limitation. Bioresour. Technol. 2009;100:3921-3926.

3. Dean AP, Sigee DC, Estrada B, Pittman JK. Using FTIR spectroscopy for rapid determination of lipid accumulation in response to nitrogen limitation in freshwater microalgae. Bioresour Technol. 2010;101(12):4499-4507.

4. Wu HQ, Miao X. Biodiesel quality and biochemical changes of microalgae Chlorella pyrenoidosa and Scenedesmus obliquus in response to nitrate levels. Bioresour Technol. 2014;170:421-427. doi: 10.1016/j.biortech.2014.08.017

5. Griffiths MJ, Harrison STL. Lipid productivity as a key characteristic for choosing algal species for biodiesel production. Journal of Applied Phycology. 2009;21:493-507.

6. Wang ZT, Ullrich N, Joo S, Waffenschmidt S, Goodenough U. Algal lipid bodies: stress induction, purification, and biochemical characterization in wild-type and starchless Chlamydomonas reinhardtii. Eukaryot Cell. 2009;8(12):1856-1868. doi: 10.1128/EC.00272-09

7. Work VH, Radakovits R, Jinkerson RE, Meuser JE, Elliott LG, Vinyard DJ, et al. Increased lipid accumulation in the Chlamydomonas reinhardtii sta7-10 starchless isoamylase mutant and increased carbohydrate synthesis in complemented strains. Eukaryot Cell. 2010;9(8):12511261. doi: 10.1128/EC.00075-10

8. Li X, Hu HY, Gan K, Sun YX. Effects of different nitrogen and phosphorus concentrations on the growth, nutrient uptake, and lipid accumulation of a freshwater microalga Scenedesmus sp. Bioresour Technol. 2010;101(14):5494-5500. doi: 10.1016/j.biortech.2010.02.016

9. Sun N, Wang Y, Li YT, Huang JC, Chen F. Sugar-based growth, astaxanthin accumulation and carotenogenic transcription of heterotrophic Chlorella zofingiensis (Chlorophyta). Process Biochem.2008;43(11):1288-1292.

10. Isleten-Hosoglu M, Gultepe I, Elibol M. Optimization of carbon and nitrogen sources for biomass and lipid production by Chlorella saccharophila under heterotrophic conditions and development of Nile red fluorescence based method for quantification of its neutral lipid content. Biochem Eng J. 2012;61:11-19.

11. Guillard RRL, Ryther JH. Studies on marine planktonic diatoms I. Cyclotella nana Hustedt and Detonula confervacea (Cleve) Gran. Can J Microbiol. 1962;8:229-239.

12. Becker EW. Microalgae: Biotechnology and Microbiology. Cambridge University Press, New York. 1994.

13. Whyte JC. Biochemical composition and energy content of six species of phytoplankton used in mariculture of bivalves. Aquaculture. 1987;60(3-4):231-241.

14. Ruangsomboon S. Effects of different media and nitrogen sources and levels on growth and lipid of green microalga Botryococcus braunii KMITL and its biodiesel properties based on fatty acid composition. Bioresour Technol. 2015;191:377-384. doi: 10.1016/j. biortech.2015.01.091

15.Shen QH, Jiang JW, Chen LP, Cheng LH, Xu XH, Chen HL. 2015. Effect of carbon source on biomass growth and nutrients removal of Scenedesmus obliquus for wastewater advanced treatment and lipid production. Bioresour Technol. 2015;190:257-263. doi: 10.1016/j. biortech.2015.04.053
16. Ping ZY, Hui SD, Lan YG. Effects of different nitrogen sources on growth and lipid accumulation of a heterotrophic microalgae Chorella vulgaris. Acta Hydrobiologica Sinica. . 2012;36:1027-1034.

17. Li T, Zheng Y, Yu L, Chen S. 2013. High productivity cultivation of a heat resistant microalga Chlorella sorokiniana for biofuel production. Bioresour Technol. 2013;131:60-67. doi: 10.1016/j. biortech.2012.11.121

18. Ramanna L, Guldhe A, Rawat I, Bux F. The optimization of biomass and lipid yields of Chlorella sorokiniana when using wastewater supplemented with different nitrogen sources. Bioresour Technol. 2014;168:127-135. doi: 10.1016/j.biortech.2014.03.064

19. Prabakaran P, David Ravindran A. Influence of different carbon and nitrogen sources on growth and $\mathrm{CO}_{2}$ fixation of microalgae. Pelagia Research Library Advances in Applied Science Research. 2012;3(3):1714-1717.

20. Velichkova K. Effect of different nitrogen sources on the growth of microalgae Chlorella vulgaris cultivation in aquaculture wastewater. Food and Agriculture Organization of United Nations. 2014;6(3):337340.

21. Liu J, Huang JC, Fan KW, Jiang Y, Zhong YJ, Sun Z, Chen F. Production potential of Chlorella zofingienesis as a feedstock for biodiesel. Bioresour Technol. 2010;101(22):8658-8663. doi: 10.1016/j. biortech.2010.05.082

22. Mandal S, Mallick N. 2009. Microalga Scenedesmus obliquus as a potential source for biodiesel production. Appl Microbiol Biotechnol. 2009;84(2):281-291. doi: 10.1007/s00253-009-1935-6

23. Ho SH, Chen CY, Chang JS. Effect of light intensity and nitrogen starvation on $\mathrm{CO}_{2}$ fixation and lipid/ carbohydrate production of an indigenous microalga Scenedesmus obliquus CNW-N. Bioresour Technol. 2012;113:244-252.

24. Yeh KL, Chang JS. Effects of cultivation conditions and media composition on cell growth and lipid productivity of indigenous microalga Chlorella vulgaris ESP-31. Bioresour Technol.2012;105:120127.

25.Ji F, Liu Y, Hao R, Li G, Zhou YG, Dong RJ. Biomass Production and Nutrients Removal by a New Microalgae Strain Desmodesmus sp. in anaerobic digestion wastewater. Bioresour Technol. 2014;161:200207. doi: 10.1016/j.biortech.2014.03.034

26. Shi X, Zhang X, Chen F. Heterotrophic production of biomass and lutein by Chlorella protothecoides on various nitrogen sources. Enzyme Microb Technol. 2000;27(3-5):312-318.

27. Rodolfi L, Zittelli GC, Bassi N, Padovani G, Biondi N, Bonini G, et al. Microalgae for oil: Strain selection, induction of lipid synthesis and outdoor mass cultivation in a low-cost photobioreactor. Biotechnol Bioeng. 2009;102(1):100-112. doi: 10.1002/bit.22033

28. Gonzalez-Garcinuno A, Tabernero A,Sanchez-Alvarez JM, del Valle EMM, Galan MA. Effect of nitrogen source on growth and lipid accumulation in Scenedesmus abundans and Chlorella ellipsoidea. Bioresour Technol. 2014;173:334-341. doi: 10.1016/j.biortech.2014.09.038

29. Zhan J, Hong Y, Hu H. Effects of nitrogen sources and C/N ratios on the lipid-producing potential of Chlorella sp. HQ. J Microbiol Biotechnol. 2016;26(7):1290-1302. doi: 10.4014/jmb.1512.12074 
30. Leesing R, Papone T, Puangbut M. Effect of nitrogen and carbon sources on growth and lipid production from mixotrophic growth of Chlorella sp. KKU-S2. International Journal of Biological, Biomolecular, Agricultural, Food and Biotechnological Engineering. 2014;8:369-372.

31. Xu N, Zhang X, Fan X, Han L, Zeng C. Effects of nitrogen source and concentration on growth rate and fatty acid composition of Ellipsoidion sp. (Eustigmatophyta). J. Appl. Phycol. 2001;13:463-469.

32. Dayananda C, Sarada R, Bhattacharya S, Ravishankar GA. Effect of media and culture conditions on growth and hydrocarbon production by Botryococcus braunii. J. Proc. Biochem. 2005;40(1):3125-3131.

33. Li Y, Horsman M, Wang B, Wu N, Lan CQ. Effects of nitrogen sources on cell growth and lipid accumulation of green alga Neochloris oleoabundans. Appl Microbiol Biotechnol. 2008;81(4):629-636. doi: 10.1007/s00253-008-1681-1

34. Lin Q Lin J. Effects of nitrogen source and concentration on biomass and oil production of a Scenedesmus rubescens like microalga. Bioresour Technol. 2011;102(2):1615-1621. doi: 10.1016/j. biortech.2010.09.008

35. Ren HY, Liu BF, Ma C, Zhao L, Ren NQ. A new lipid-rich microalga Scenedesmus sp. strain R-16 isolated using Nile red staining: effects of carbon and nitrogen sources and initial $\mathrm{pH}$ on the biomass and lipid production. Biotechnol Biofuels. 2013;6(1):143. doi: 10.1186/17546834-6-143

36. Sibi G. Cultural conditions and nutrient composition as effective inducers for biomass and lipid production in fresh water microalgae. Research Journal of Environmental Toxicology. 2015;9(4):168-178.

37. Illman AM, Scragg AH, Shales SW. Increase in Chlorella strains calorific values when grown in low nitrogen medium. Enzyme Microb Technol. 2000;27(8):631-635.
38. Xiong W, Li X, Xiang J, Wu Q. High-density fermentation of microalga Chlorella protothecoides in bioreactor for microbio diesel production. Appl Microbiol Biotechnol. 2008;78(1):29-36.

39. Converti A, Casazza AA, Ortiz EY, Perego P, Borghi MD. Effect of temperature and nitrogen concentration on the growth and lipid content of Nannochloropsis oculata and Chlorella vulgaris for biodiesel production. Chemical Engineering and Processing. 2009;48(6):11461151.

40.Shen Y, Yuan W, Pei Z, Mao E. Heterotrophic culture of Chlorella protothecoides in various nitrogen sources for lipid production. Appl Biochem Biotechnol. 2010;160(6):1674-1684. doi: 10.1007/s12010009-8659-z

41. Feng P, Z Deng, L Fan, Z Hu. Lipid accumulation and growth characteristics of Chlorella zofingiensis under different nitrate and phosphate concentrations. J Biosci Bioeng. 2012;114(4):405-410. doi: 10.1016/j.jbiosc.2012.05.007

42. Amin NF, Khalafallah MA, Ali MA, Abou-Sdera SA, Matter IA. Effect of some nitrogen sources on growth and lipid of microalgae Chlorella sp. for biodiesel production. J. Appl. Sci. Res. 2013;9:4845-4855.

43. Fei Q, Fu R, Shang L, Brigham CJ, Chang HN. Lipid production by microalgae Chlorella protothecoides with volatile fatty acids (VFAs) as carbon sources in heterotrophic cultivation and its economic assessment. Bioprocess Biosyst Eng. 2015;38(4):691-700. doi: 10.1007/s00449-014-1308-0

44. Choi JA, DY Kim, YH Seo, JI Han. 2016. Application of Fe( $\left(\mathrm{NO}_{3}\right)_{3}$-based as nitrogen Source and coagulant for cultivation and harvesting of Chlorella sorokiniana. Bioresour Technol. 2016;222:374-379. 